\title{
SOSIALISASI MENGENAI PENYEBARAN COVID-19 DAN PENCEGAHAN INFEKSI PADA MASYARAKAT KELURAHAN MASJID
}

\author{
Ririen Hermina ${ }^{1}$, Novitawati ${ }^{2}$, Nurhadi Ramadhan ${ }^{3}$, M. Yusuf Isnaini ${ }^{4}$, Fierissya Aldiba \\ Sukma $^{5}$, Windi Karina ${ }^{6}$, Melsandi ${ }^{7}$, Irpan Firdaus ${ }^{8}$, Aprillia Mayang Sari ${ }^{9}$, Windra ${ }^{10}$, \\ Insan Kurniawan ${ }^{11}$, Sasih Karnita Arafatun ${ }^{12}$ \\ 1,2,3,4,5,6,7,8,8,9,10,11,12 Universitas Muhammadiyah Bangka Belitung \\ Email: ririenrh@gmail.com ${ }^{1}$
}

\begin{abstract}
ABSTRAK
Pandemi COVID-19 masih menjadi suatu permasalahan bagi masyarakat Indonesia, terutama pada daerah-daerah tertentu yang masih belum mendapatkan cukup edukasi mengenai pandemi COVID-19 itu sendiri. Hal ini terkadang menimbulkan suatu kebingungan bagi masyarakat awam, bahkan masih banyak masyarakat yang menganggap sepele mengenai pandemi COVID-19 ini. Adanya pemberian sosialisasi/penyuluhan mengenai pandemi COVID-19 kepada masyarakat, agar masyarakat mengetahui apa sebenarnya pandemi COVID-19 mulai dari penyebarannya, gejala, sampai dengan bagaimana sikap yang harus dilakukan ketika diri sendiri atau pada orang lain yang terkena COVID-19. Metode yang digunakan dalam kegiatan ini adalah penyuluhan secara ceramah dan tanya jawab. Materi diisi oleh tenaga kesehatan yang memang sudah mumpuni pada bidangnya. Pelaksanaan sosialisasi ini pada tanggal 20 Februari 2021 yang dilaksanakan di Aula Kelurahan Masjid Jamik dengan peserta sosialisasi berupa masyarakat sekitar. Diharapkan dengan diadakannya sosialisasi ini, masyarakat dapat menjadi lebih awas dan peka terhadap keadaan sekitarnya dan dapat menjaga diri sendiri serta orang lain di lingkungannya.
\end{abstract}

\section{Kata Kunci: Pandemi, COVID-19, Vaksin}

\section{PENDAHULUAN}

Corona Viruses Diseases 19 atau yang lebih dikenal dengan sebutan COVID-19 mulai masuk ke Indonesia pada pertengahan tahun 2020 lalu. Di Indonesia, pandemi ini masih menjadi suatu permasalahan dikarenakan masih tingginya angka masyarakat yang terdampak COVID, diikuti dengan jumlah kematian yang cukup tinggi dimana angka terdampak akibat kasus ini mencapai satu juta. Dilansir dari WHO melalui detik.com, insidensi kematian akibat COVID-19 di Indonesia sekitar 0,34 per 100.000 populasi atau 3,4 persen. Angka ini dikategorikan cukup tinggi dibanding negara-negara lain yang sudah mengalami angka penurunan pada dampak COVID-19.

Peningkatan kasus COVID-19 yang sangat cepat di Indonesia, di dukung oleh proses penyebaran yang cepat baik dari hewan ke manusia, atau dari manusia ke manusia. Proses penularan virus adalah melalui pengeluaran droplet SARS-CoV-2 oleh orang yang terinfeksi pada saat batuk ataupun bersin. Droplet ini lalu menyebar di udara, dan dapat menginfeksi orang lain di dekatnya ketika terhirup baik melalui hidung ataupun mulut. Hal ini dapat menjadi 
ancaman bagi masyarakat dimana dapat menyebabkan kasus terdampak COVID-19 menjadi meningkat (Shereen, Khan, Kazmi, Bashir, \& Siddique, 2020).

Pemerintah sudah mengupayakan cara untuk mengurangi terjadinya penularan COVID19 terhadap masyarakat yaitu disebut dengan PHBS (Perilaku Hidup Bersih dan Sehat). Hal-hal yang harus dilakukan selama pandemi COVID ialah mencuci tangan dengan sabun atau dengan bahan yang mengandung alkohol, menggunakan masker, tidak menyentuh mata, mulut, dan hidung sebelum mencuci tangan, menjaga jarak dan tidak melakukan kontak dengan orang yang terinfeksi (Di Gennaro, dkk. 2020). Di Bangka Belitung sendiri, dilansir dari data pada web covid19.go.id, kasus terdampak COVID-19 mencapai 6.000 kasus.

Edukasi mengenai PHBS sudah seringkali dilakukan, namun pada kenyataan di lapangan masih banyak masyarakat yang tidak memperhatikan hal tersebut. Masih saja ada warga yang tidak menggunakan masker, masih banyak warga yang tidak menjaga jarak dan berkerumunan (umumnya pada suatu acara), warga juga seringkali tidak mencuci tangan dengan sabun atau bahan berbasis alkohol ketika sampai di suatu tempat umum. Selain itu, masih ada masyarakat yang kurang paham mengenai bagaimana cara menanggapi orang lain yang terdampak atau ketika diri sendiri terdampak COVID-19. Beberapa masyarakat yang ditemui masih menganggap bahwa COVID-19 adalah sebuah aib sehingga terkadang pasien terdampak COVID-19 dikucilkan dan tidak diberi dukungan moral dari masyarakat.

Masyarakat juga masih banyak mendengar stigma jelek baik dari media sosial maupun secara mulut ke mulut mengenai pengendalian infeksi dengan vaksin, sehingga kebanyakan orang takut untuk melaksanakan vaksinasi. Hal ini menyebabkan adanya kesalahpahaman masyarakat terhadap vaksinasi COVID-19. Padahal, hal ini dapat membantu mengurangi kasus terdampak COVID-19 yang terjadi pada masyarakat. Dari permasalahan berikut, masyarakat masih sangat membutuhkan informasi fakta mengenai pandemi COVID-19. Hal ini lebih efektif dilakukan apabila penyampaian materi dilakukan tenaga kesehatan terutama yang pernah menangani kasus pandemi COVID-19. Dikarenakan mereka akan lebih paham mengenai hal tersebut.

Pentingnya diadakan kegiatan ini adalah agar masyarakat lebih mengerti bagaimana cara untuk menjaga diri sendiri dan orang lain dari pandemi COVID-19. Kegiatan ini juga dilaksanakan sebagai upaya untuk memberi pengertian kepada masyarakat mengenai vaksinasi COVID-19 saat ini. Diharapkan dengan adanya sosialisasi ini, masyarakat lebih bisa dalam bersikap apabila nantinya menanggapi kondisi terdampak COVID-19.

\section{METODE}

A. Tahapan Kegiatan

1. Tahap Persiapan

a. Pada tahap ini dilakukan perhitungan kebutuhan sosialisasi dan konsolidasi dengan pihak mitra.

b. Pembuatan spanduk sosialisasi sebagai wajah dari terlaksananya sosialisasi. 
c. Pemilihan kriteria peserta sosialisasi yaitu masyarakat seputar Kelurahan Masjid Jamik yang bersedia berpastisipasi dalam gerakan lawan COVID-19.

2. Pendekatan Pengabdian kepada Masyarakat

a. Pendekatan dilaksanakan dengan model penyuluhan/sosialisasi.

b. Memberikan penyuluhan kepada masyarakat mengenai pandemi COVID-19 serta pengendalian infeksi.

3. Partisipasi Mitra

a. Mengakodinir peserta sosialisasi dan bersedia dalam mengikuti sosialisasi.

b. Mengikuti sosialisasi dengan baik dan serius.

c. Memberikan komentar setelah dilaksanakannya sosialisasi.

\section{HASIL DAN PEMBAHASAN}

Mahasiswa Universitas Muhammadiyah Bangka Belitung melaksanakan kegiatan pengabdian masyarakat di Kelurahan Masjid Jamik, Kecamatan Rangkui, Kota Pangkalpinang. Kelurahan Masjid Jamik terletak dekat dengan pusat Kota Pangkalpinang. Lokasi pengabdian masyarakat ini dipilih dikarenakan adanya pandemi COVID-19 sehingga mahasiswa peserta kuliah kerja nyata $(\mathrm{KKN})$ ditempatkan di daerah yang dekat dengan tempat tinggal masingmasing, sesuai dengan tema yang diangkat yaitu "Agen Perubahan Balik Kampung: Berkontribusi dalam Percepatan Penanggulangan COVID-19). Kegiatan pengabdian masyarakat yang dilaksanakan oleh mahasiswa adalah sosialisasi mengenai pandemi COVID19 kepada masyarakat di Kelurahan Masjid Jamik. Kegiatan ini dilaksanakan pada hari sabtu tanggal 20 Februari 2021. Kegiatan ini dilaksanakan dengan bekerja sama dengan perangkat Kelurahan Masjid Jamik.

Peserta kegiatan pengabdian kepada masyarakat, melibatkan masyarakat yang bertempat tinggal di Kelurahan Masjid Jamik mulai dari perangkat Kelurahan sampai dengan masyarakat umum. Peserta yang mengikuti sosialisasi sekitar 20 orang. Ketua dari kegiatan ini adalah Nurhadi Ramadhan, selaku ketua kegiatan KKN di Kelurahan Masjid Jamik.

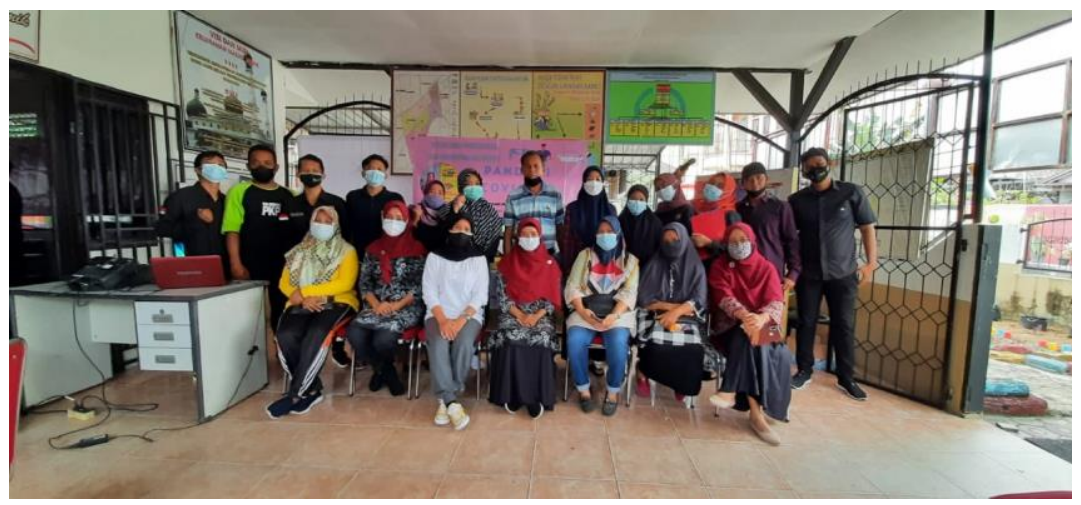

Gambar 1. Setelah pelaksanaan sosialisasi COVID-19 
Kegiatan pengabdian masyarakat ini dilaksanakan untuk menjaga dan meningkatkan derajat kesehatan masyarakat, serta membangun kesadaran masyarakat mengenai pandemi COVID-19 yang sedang terjadi saat ini. Sosialisasi mengenai pandemi COVID-19 dan pencegahan infeksi ini dilakukan sebagai upaya pencerahan bagi masyarakat. Masyarakat diharapkan dapat menghadap pandemi COVID-19 secara bijak. Maka dari itu perlu dilakukan sosialisasi terhadap masyarakat di Kelurahan Masjid Jamik.

Materi sosialisasi yang diberikan yaitu mengenai asal usul virus corona, awal mula virus corona masuk ke Indonesia, dan bagaimana gejala gejala orang yang terdampak virus corona. Selain itu mengajarkan masyarakat mengenai PHBS yaitu penggunaan masker yang baik dan benar, serta cara mencuci tangan yang baik. Melihat kondisi masyarakat, masyarakat perlu diberikan edukasi agar dapat menyikapi pandemi COVID-19 dengan bijaksana. Menurut Ni Putu Emy Darma Yanti, dkk (2020) dengan pengetahuan masyarakat yang baik, diharapkan dapat meningkatkan perilaku masyarakat dalam menjalankan perilaku hidup sehat (PHBS) dan meningkatkan kepatuhan dalam menerapkan protokol kesehatan.

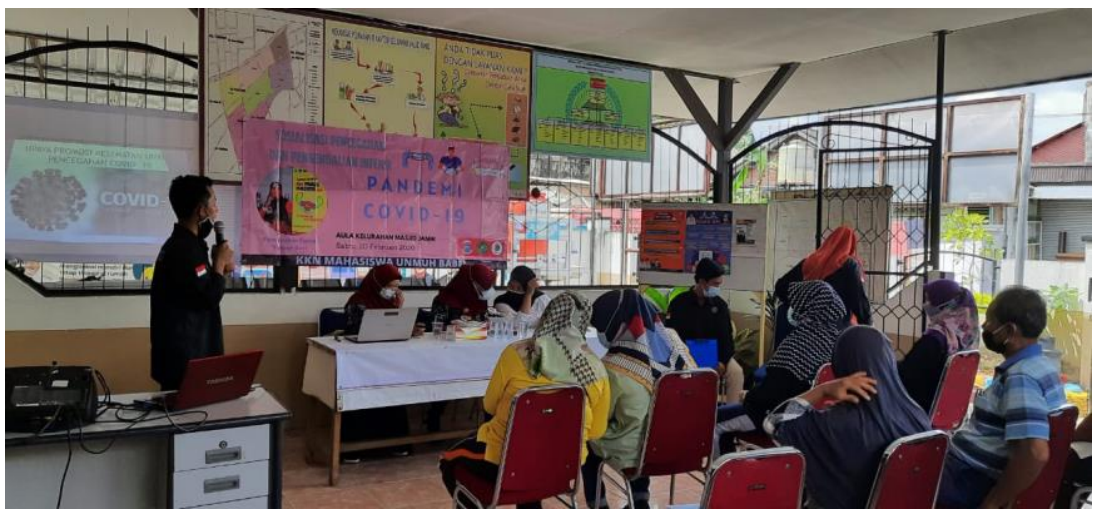

Gambar 2. Proses Sosialisasi COVID-19

Sosialisasi dilaksanakan selama dua jam, dimulai pada pukul 10.00 WIB sampai dengan 12.00 WIB. Pihak Kelurahan Masjid Jamik mengharapkan adanya kelanjutan dari kegiatan ini, misalnya saja pembagian masker serta edukasi bagi masyarakat yang belum mematuhi protokol kesehatan yang telah ditetapkan oleh pemerintah. Kegiatan pengabdian masyarakat ini diharapkan terus berlanjut selama kondisi pandemi COVID-19 sehingga tujuan yang diinginkan pada Kelurahan Masjid Jamik, Kecamatan Rangkui mendapatkan wujud nyata terhadap peningkatan kesehatan masyarakat.

\section{KESIMPULAN}

Setelah dilakukan sosialisasi mengenai pencegahan COVID-19 dan pengendalian infeksi terdapat peningkatan pengetahuan yang cukup signifikan tentang gejala COVID-19, 
bagaimana cara mencegah penularan COVID-19, melaksanakan PHBS secara baik dan benar, dan manfaat melaksanakan PHBS. Hal ini menunjukkan keefektifitasan penyuluhan/sosialisasi oleh tenaga kesehatan sebagai pembicara. Selain itu didukung oleh media power point yang dilengkapi dengan materi COVID-19 yang dibuat secara interaktif.

\section{UCAPAN TERIMAKASIH}

Keberlangsungan kegiatan pengabdian masyarakat ini dapat terlaksana dengan baik dengan adanya dukungan dari pihak pihak yang terkait, serta LPPM Universitas Muhammadiyah Bangka Belitung. Terimakasih juga diucapkan untuk perangkat Kelurahan Masjid Jamik serta masyarakat Kelurahan Masjid Jamik.

\section{DAFTAR PUSTAKA}

Di Gennaro, F., Pizzol, D., Marotta, C., Antunes, M., Racalbuto, V., Veronese, N., \& Smith, L. (2020). Coronavirus diseases (COVID-19) current status and future perspectives: A narrative review. International Journal of Environmental Research and Public Health, 17(8)

Emy Darma Yanti, Ni Putu, dkk. (2020). Gambaran Pengetahuan Masyarakat Tentang COVID19 dan Perilaku Masyarakat di Masa Pandemi Covid-19. Jurnal Keperawatan Jiwa, 8(3), 501 Khadijah Nur Azizah. 2020. WHO: Angka Kematian COVID-19 di Indonesia Lebih Tinggi dari Dunia. Diakses pada 22 Februari 2021 from https://health.detik.com/berita-detikhealth/d5282583/who-angka-kematian-covid-19-di-indonesia-lebih-tinggi-dari-dunia.

Shereen, M. A., Khan, S., Kazmi, A., Bashir, N., \& Siddique, R. (2020). COVID-19 infection: Origin, transmission, and characteristics of human coronaviruses. Journal of Advanced Research, 24(1), 91-98 